course of chronic hepatitis D in our cohort of HIV-immunosuppressed patients, and we postulate that high replication of the delta virus and the presence of $\mathrm{HCV}$ co-infection, in conjunction, could explain this worse outcome.

MONTSE DE POUPLANA
VICENC SORIANO
JAVIER G. SAMANIEGO
ANA ENRÍQUEZ
FERNANDO MUNOZ
JUAN GONZÁLEZ-LAHOZ
Department of Infectious Diseases, Gastroenterology,
and Microbiology,
Instituto de Salud Carlos III, Madrid.

Address correspondence to Dr Vincent Soriano, C/RafaelCalvo 7, $2^{\circ}$ A 28010-Madrid, Spain.

1 Horvath J, Raffanti S. Clinical aspects of the interactions between HIV and the hepatotropic viruses. Clin Infect between HIV and the

Dis 1994;18:339-47.
2 Reddy K, De Medina M, Jeffers L, et al. HCV-RNA by signal amplification bDNA assay in HIV and HCV coinfection (Abstract). 94th Annual Meeting of the AGA, Boston, May 1993. Gastroenterology 1993; 104(supl):A767.

3 Martin P, Di Bisceglie A, Kassianides C, Lisker-Melman $M$, Hoofnagle J. Rapidly progressive Non-A, Non-B hepatitis in patients with HIV infection. Gastroenterology 1989;97:1559-61.

4 Novick D, Farci P, Croxson T. Hepatitis D virus and HIV antibodies in parenteral drug abusers who are $\mathrm{HBsA}$ positive. F Infect Dis 1988;158:795-803.

5 Soriano V, García-Samaniego J, Gutierrez M, Bravo R, González-Lahoz J. High morbidity and mortality with chronic viral liver disease in HIV-infected individuals in chronic viral liver disease in HIV
Spain. F Infection 1994;28:100-1.

6 Rizzetto M, Ponzetto A, Bonino F, Smedile A. Hepatitis delta virus infection: clinical and epidemiological delta virus infection: clinical and epidemiological aspects. In: Zuckerman A, ed. Viral Hepatitis
Disease. New York: Alan R Liss 1988;389-94.

7 Pontisso P, Ruvoletto M, Fattovich G, et al. Clinical and virological profiles in patients with multiple hepatitis virus infections. Gastroenterology 1993;105:1529-33.

8 García-Samaniego J, Soriano V, Bravo R, González-Lahoz $J$, Muñoz F. Viral replication in patients with multiple hepatitis virus infections: lack of reciprocal influence in HIV-infected subjects. Gastroenterology 1994;107:323.

Accepted for publication 31 October 1994

\section{Spontaneous loss of PPNG resistance plasmids}

The Scottish Neisseria gonorrhoeae Reference Laboratory Annual Report for $1992^{1}$ highlighted one of the points made in the study on gonococcal epidemiological data ${ }^{2}$ from Stockholm, Sweden.

A small cluster of penicillinase-producing Neisseria gonorrhoeae (PPNG) infection in Central Region, Scotland, demonstrated spontaneous loss of plasmid encoding during the process of clinical assessment, screening and treatment. Patient 1 who attended on 17 August 1992 with minor vulvodynia (and who had had a hysterectomy in 1986) was found to have a gonococcal infection with a PPNG isolate of serovar IB-1/Bopst. Her partner, who was contact traced on 2 September 1992 and reported a casual contact in Tenerife, was also shown to be infected with a IB-1/Bopst PPNG isolate. It is of interest that the casual contact originated from a Scottish Health Board Area (Fife) adjacent to Central Region. Patient 3 (no connection with nos 1 \& 2) attended with urinary symptoms on 10 September 1992 with positive microscopy and a IB-1/Bopst non-PPNG isolate was reported. His partner was contact traced on 11
September 1992, had complained of cystitis over a five month period, and a IB-1/Bopst PPNG (showing a weak reaction in the chromogenic cephalosporin test) was isolated; the culture was later shown to contain both penicillin sensitive and penicillin resistant IB-1 isolates. A repeat culture from the same patient received one week later was found to be IB-1/Bopst non-PPNG. All of the PPNG isolates carried $2 \cdot 6,3.05$ and $24.5 \mathrm{MDa}$ plasmids, were non-requiring (NR) on auxotyping and had a ciprofloxacin MIC of $0.06 \mathrm{mg} / 1$. The non-penicillinase isolates were also auxotype NR with a ciprofloxacin MIC of 0.06 $\mathrm{mg} / \mathrm{l}$. There were no other IB-1/Bopst strains isolated in Scotland during 1992.

As all patients were contact traced, the cluster of infection was contained with the added bonus of demonstrable spontaneous loss of $\beta$-lactamase plasmid during surveillance. This report also highlights the importance of national surveillance. It is unlikely that the probable source of infection in Tenerife, who originated from Fife, has returned to Scotland with an infection as this would have been detected through the Scottish Neisseria gonorrhoeae Reference Laboratory.

$$
\begin{array}{r}
\text { J M HARVEY } \\
\text { Falkirk E District Royal Infirmary NHS Trust, } \\
\text { Falkirk, } \\
\text { Scotland } \\
\text { HUGH YOUNG } \\
\text { The University of Edinburgh Medical School, } \\
\text { Edinburgh, UK }
\end{array}
$$

Young $\mathrm{H}$, Moyes A. Gonococcal infections within Scotland: antigenic heterogeneity and antibiotic suscepScotland: antigenic heterogeneity and antibiotic suscep-
tibility of infecting strains. Communicable Diseases and tibility of infecting strains. Communicable Diseases and Environmental Health

2 Ruden AK. Temporal changes in the gonococcal serovar patterns in Stockholm during two years with special reference to PPNG strains. Genitourin Med 1994;70: 256-61.

Accepted for publication 25 October 1994

\section{Disseminated infection due to penicillin resistant gonococci-is it still rare?}

Penicillin resistant gonococci have only rarely been implicated in disseminated gonococcal infection. Two reports attributed two separate cases of gonococcal arthritis to penicillinase producing organisms but these cases were not well documented. ${ }^{12}$ In neither case was the organism cultured directly from a disseminated site and the relation of the arthritis to the gonococcal infection was presumptive, being based on positive throat or urethral cultures. However, five cases of gonococcal arthritis due to penicillinase producing organisms that were cultured directly from infected joints have been reported. ${ }^{3}$ As an addition to these cases, we describe a case of gonococcal arthritis due to penicillinase producing organisms, based on culture from the infected joint.

A 25 year old West Indian woman was admitted to the orthopaedic department in September 1993 with a history that following return from Jamaica, she was suffering from flitting joint pain affecting particularly her 
right ankle, knee, shoulder and more recently, her left wrist. Physical examination on admission was unremarkable apart from the presence of a left wrist effusion, with associated warmth, erythema and tenderness causing limited extension and flexion. She was initially treated with amoxicillin but this was changed to augmentin following the culture report of the aspirated fluid from her left wrist, which revealed a beta lactamase producing gonococcus, penicillin resistant and sensitive to augmentin.

She attended (as a self-referral and not referred by the orthopaedic department) at our Genitourinary Medicine Clinic three days following her discharge from the hospital. She was complaining of yellow/greenish vaginal discharge.

She admitted to having two sexual partners, one of whom was a casual contact whilst in Jamaica four weeks prior to her admission. The other was a regular male partner for the past three years with whom she had unprotected sex two weeks prior to her presentation in the Genitourinary Medicine Clinic. The regular boyfriend attended the Department of GU Medicine in Coventry with her. $\mathrm{He}$ was complaining of recurrent penile discharge of ten days duration. He was subsequently found to have a penicillin resistant gonococcal urethritis and he was treated with spectinomycin. In addition, both the patient and her regular partner were found to have chlamydia. They were both treated for this with a course of tetracycline. The female partner did not show any evidence of gonococcal infection during her attendance at our clinic. This was because she had received anti-gonococcal treatment prior to her presentation at this clinic. The patient's regular partner had also had a casual contact in the United Kingdom, who attended a GUM Clinic elsewhere and was found to have a penicillin resistant gonococcal infection.

This case serves to demonstrate an unusual occurrence, the disseminated infection due to penicillin resistant gonorrhoea. In addition, it demonstrates how colleagues in other specialities are still unaware or reluctant to refer patients to genitourinary medicine clinics with sexually transmitted diseases.

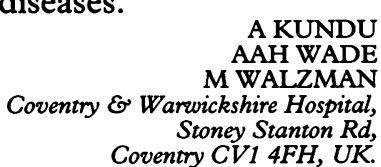

Address correspondence to Dr Kundu.

1 Percival A, Rowlands J, Corkill JE, et al. Penicillinaseproducing gonococci in Liverpool. Lancet 1976;ii: 1379-82.

2 Leftik MI, Miller JW, Brown JD Penicillin-resistan

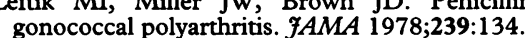

3 Rinaldi ZR, Harrison WO, Fan PT. Penicillin-resistant gonococcal arthritis. A report of four cases. Ann Intern Med 1982;97:43-5.

Accepted for publication 12 October 1994
Single dose trimethoprim-sulphamethoxazole for treatment of chancroid

Chancroid is one of the major causes of genital ulcer disease in developing countries. ${ }^{1}$ Sexually transmitted pathogen Haemophilus ducreyi is primarily held responsible for it. The ulcers are acute in onset, painful, sometimes highly destructive and often associated with painful, suppurative, inguinal lymphadenopathy.

Randomised double blind studies from different parts of the world (mainly from Asia and Africa) have shown effectiveness of trimethoprim-sulphamethoxazole (TMP$S M Z$ ) or its congeners when given for five to
14 days. $^{2-4}$ Plummer et $a l^{5}$ demonstrated that TMP-SMZ when administered in a single eight tablet dose of $640 \mathrm{mg} / 3200 \mathrm{mg}$ was convenient, and $96 \%$ curative. Other studies particularly from Nairobi using similar preparations in a single dosage have been shown to be effective. ${ }^{78}$ The cure rate for chancroid ulcers varied from as low as $30 \%^{6}$ to $100 \%^{8}$ whereas that for buboes ranged from $67 \%^{7}$ to $100 \% .^{5}$ However, a study from Thailand reported a cure rate of only $55 \%$ for chancroid ulcer (table).

The present study was carried out to evaluate the efficacy of such single dose therapy in our local population.

Patients with classical chancroid (both

Different single dose trimethoprim sulphonamide combination therapy for chancroid

\begin{tabular}{|c|c|c|c|c|c|c|}
\hline \multirow[b]{2}{*}{ Location } & \multirow[b]{2}{*}{ Antimicrobial } & \multicolumn{3}{|c|}{ Ulcers (\%) } & \multicolumn{2}{|c|}{ Buboes (\%) } \\
\hline & & $\begin{array}{l}\text { No. of } \\
\text { patients }\end{array}$ & Cured & Improved & $\begin{array}{l}\text { No. of } \\
\text { patients }\end{array}$ & Cured \\
\hline Nairobi ${ }^{6}$ & $\begin{array}{l}\text { Trimethoprim } 640 \mathrm{mg}+ \\
\text { Sulphamethoxazole } 3200 \mathrm{mg}\end{array}$ & 10 & $3(30 \%)$ & $6(60 \%)$ & - & - \\
\hline Nairobi $^{5}$ & $\begin{array}{l}\text { Trimethoprim } 640 \mathrm{mg}+ \\
\text { Sulphamethoxazole } 3200 \mathrm{mg}\end{array}$ & 25 & $24(96 \%)$ & - & 11 & $11(100 \%)$ \\
\hline Nairobi ${ }^{7}$ & $\begin{array}{l}\text { Trimethoprim } 640 \mathrm{mg}+ \\
\text { Sulphamethoxazole } 3200 \mathrm{mg}\end{array}$ & 27 & $21(78 \%)$ & - & 9 & $6(67 \%)$ \\
\hline Nairobi $^{8}$ & $\begin{array}{l}\text { Trimethoprim } 640 \mathrm{mg}+ \\
\text { Sulphamethoxazole } 3200 \mathrm{mg}\end{array}$ & 27 & $27(100 \%)$ & - & 6 & $5(83 \%)$ \\
\hline $\begin{array}{l}\text { Bangkok }{ }^{2} \text {, } \\
\text { Thailand }\end{array}$ & $\begin{array}{l}\text { Trimethoprim } 640 \mathrm{mg}+ \\
\text { Sulphamethoxazole } 3200 \mathrm{mg}\end{array}$ & 31 & $17(55 \%)$ & - & - & - \\
\hline Present study & $\begin{array}{l}\text { Trimethoprim } 960 \mathrm{mg}+ \\
\text { Sulphamethoxazole } 4800 \mathrm{mg}\end{array}$ & 11 & $2(18 \%)$ & $3(27 \%)$ & 5 & $1(20 \%)$ \\
\hline
\end{tabular}

